\title{
PEMANFAATAN LIMBAH PADAT IPAL INDUSTRI TEKSTIL SEBAGAI PENGGANTI SEBAGIAN AGREGAT HALUS PADA BETON
}

\author{
Iristyaningrum Wiyono Sittati Musalamah, Anisah
}

\begin{abstract}
Abstrak
Penelitian ini bertujuan untuk mengetahui kegunaan dari limbah padat IPAL indutri tektil pada kuat tekan beton pada benda uji kubus dalam upaya untuk mendapatkan proporsi maksimum pada beton dengan menggunakan 4 perlakuan yaitu, 0\%, 20\%, 40\% dan 60\% dari jumlah berat agregat halus untuk rancangan beton f'c 25 Mpa dengan slump $120 \pm 20 \mathrm{~mm}$.

Penelitian ini dilaksanakan di Laboraturium Kimia Universitas Indonesia dan Laboraturium Uji Bahan Universitas Negeri Jakarta pada bulan Desember 2012 hingga Januari 2013 dengan metode eksperimen. Penelitian ini menggunakan beton dengan rancangan f'c 25 Mpa dengan slump $120 \pm 20 \mathrm{~mm}$, dengan jumlah sampel 40 benda uji berbentuk kubus.

Hasil penelitian ini menunjukan bahwa terdapat perbedaan pada penggunaan limbah padat IPAL industri tekstil dengan kuat tekan beton. Rata-rata kuat tekan tertinggi terdapat pada kandungan limbah $60 \%$ dari berat agregat halus yaitu 18,99 Mpa, tegangan karakteristik tertinggi didapat oleh beon dengan kandungan limbah 40\%, sedangkan nilai slump yang memenuhi nilai slump rencana adalah pada beton dengan kandungan limbah 20\% dari berat agregat halus yaitu 100 $\mathrm{mm}$.
\end{abstract}

Kata kunci : beton, limbah padat IPAL

Iristyaningrum Wiyono

Alumni Jurusan Teknik Sipil

Fakultas Teknik

Universitas Negeri Jakarta, 13220
Sittati Musalamah, MT Staff Pengajar Jurusan Teknik Sipil Fakultas Teknik

Universitas Negeri Jakarta, 13220
Anisah, MT

Staff Pengajar Jurusan Teknik Sipil

Fakultas Teknik

Universitas Negeri Jakarta, 13220

\section{PENDAHULUAN}

Kawasan industri telah banyak terdapat diberbagai daerah baik di Jakarta maupun di sekitarnya.

Salah satu contoh kawasan industri di Jakarta adalah Kawasan Industri Pulo Gadung, dan Kawasan Berikat Nusantara. Hasil dari suatu industri selain merupakan barang jadi adalah 
limbah. Dengan semakin berkembangnya industri dewasa ini maka semakin meningkat pula produksi limbah. Pengolahan limbah merupakan salah satu hal yang penting dalam menjaga ekosistem alam.

Limbah tekstil dari mulai pembuatan kain hingga pencucian, banyak mengandung zat organik yang sangat berbahaya bagi lingkungan yang tentu saja tidak boleh begitu saja dibuang, melainkan harus diolah terlebih dahulu. Pengolahan limbah tersebut melalui Industri Pengolahan Air Limbah atau yang biasa disebut dengan IPAL. Setelah melalui proses IPAL maka limbah padat industri tekstil tersebut akan berbentuk seperti pasir yang mengandung sedikit air. Jika limbah yang mengandung sedikit air tersebut dijemur, maka limbah tersebut akan berbentuk seperti pasir halus yang berwarna agak kehitaman.

Berdasarkan data dari salah satu kawasan perindustrian tekstil di Jakarta yang dikemukakan oleh Idaman (2005), limbah yang dihasilkan adalah 90.000 liter per harinya. Untuk menciptakan peluang - peluang baru yang perlu dilakukan terutama pada potensi limbah industri yang masih terabaikan. Salah satu potensi limbah industri yang kurang tergarap dengan baik adalah pemberdayaan dan pemanfaatan limbah industri tekstil yang telah diolah menjadi butiran-butiran kecil dan halus.

Selama ini pemanfaatan limbah padat tersebut belum optimal. Limbah ini hanya dimanfaatkan untuk menimbun areal di sekitar pabrik. Apabila keadaan ini dibiarkan terus menerus maka semakin lama akan kekurangan lahan untuk penimbunan limbah sehingga memungkinkan terjadinya pencemaran lingkungan. Dengan demikian diperlukan adanya upaya untuk mengatasi permasalahan tersebut. Bila potensi ini tergarap dengan baik, diharapkan dapat memberikan kontribusi dalam pengelolaan limbah industri sekaligus dimanfaatkan untuk material bangunan.

Dewasa ini pertumbuhan dan perkembangan industri konstruksi di Indonesia cukup besar. Hampir $70 \%$ material yang digunakan dalam pekerjaan konstruksi adalah beton yang dipadukan dengan baja atau jenis lainnya. Menurut Mulyono (2003) beton merupakan fungsi dari bahan penyusunnya yang terdiri dari bahan semen hidrolik (portland cement), agregat kasar, agregat halus, air, dan bahan tambah (admixture atau additive). Kuat tekan merupakan salah satu kinerja utama beton. 
Kekuatan tekan adalah kemampuan beton untuk menerima gaya tekan persatuan luas. Walaupun dalam beton terdapat tegangan tarik yang kecil, diasumsikan bahwa semua tegangan tekan didukung oleh beton tersebut. Selain karena kuat tekan beton yang tinggi, keunggulan beton antara lain adalah mudah dalam perawatan, mudah dalam pembentukan, serta mudah mendapatkan bahan susun. Beberapa pemakaian beton adalah untuk Apartemen, Rusunami, dan juga rumah tinggal sederhana.

Banyaknya jumlah penggunaan beton dalam konstruksi tersebut mengakibatkan peningkatan kebutuhan material beton, sehingga memicu penambangan batuan sebagai salah satu bahan pembentuk beton secara besar-besaran. Hal ini menyebabkan turunnya jumlah sumber alam yang tersedia untuk keperluan pembetonan dan perusakan lingkungan.

Bertitik tolak dari pemikiran tersebut, maka penulis ingin meneliti kuat tekan dari beton yang yang menggunakan limbah padat IPAL industri tekstil sebagai bahan pengganti sebagian agregat halus. Adapun kuat tekan yang direncanakan pada penelitian ini adalah f'c adalah $25 \mathrm{Mpa}$, sedangkan presentase limbah padat IPAL industri tekstil sebagai pengganti agregat halus adalah $0 \%, 20 \%, 40 \%$, dan $60 \%$ dari berat agregat halus yang digunakan.

\section{METODA}

\section{Bahan Penyusun Beton}

Menurut Mulyono (2003), beton merupakan fungsi dari bahan penyusunnya yang terdiri dari bahan semen hidrolik (portland cement), agregat kasar, agregat halus, air, dan bahan tambah (admixture atau additive).

Beton merupakan salah satu bahan konstruksi yang telah umum digunakan untuk bangunan gedung, jembatan, jalan, dan lain-lain. Beton merupakan satu kesatuan yang homogen (Amri,2005). Beton ini didapatkan dengan cara mencampur agregat halus (pasir), agregat kasar (kerikil), atau jenis agregat lain dan air, dengan semen portland atau semen hidrolik yang lain, kadang-kadang dengan bahan tambahan (additif) yang bersifat kimiawi ataupun fisikal pada perbandingan tertentu, sampai menjadi satu kesatuan yang homogen. 
Semen portland adalah salah satu bahan yang sangat penting dalam pembuatan beton. Meskipun komposisinya dari beton hanya 10\% namun semen mempunya fungsi yang sangat penting yaitu sebagai bahan pengikat. Menurut SNI 15-2049-2004 semen portland adalah semen hidrolis yang dihasilkan dengan cara menggiling terak semen portland terutama yang terdiri atas kalsium silikat yang bersifat hidrolis dan digiling bersama-sama dengan bahan tambahan berupa satu atau lebih bentuk kristal senyawa kalsium sulfat dan boleh ditambah dengan bahan tambahan lain.

Kandungan agregat dalam campuran beton biasanya cukup tinggi. Komposisi agregat dalam campuran beton sekitar $60-70 \%$ dari berat campuran beton. Agregat termasuk bahan yang penting dalam campuran beton karena komposinya yang cukup dominan dalam campuran beton.

Agregat kasar adalah batuan yang ukuran butirnya lebih besar dari $4.80 \mathrm{~mm}$ (British Standard) atau $4.75 \mathrm{~mm}$ (standar ASTM) dan agregat halus adalah batuan yang lebih kecil dari $4.80 \mathrm{~mm}$ (Mulyono, 2003). Agregat dengan ukuran lebih besar dari $4.80 \mathrm{~mm}$ dibagi lagi menjadi dua: yang berdiameter antara 4.80-40 mm disebut kerikil beton dan yang lebih dari $40 \mathrm{~mm}$ disebut kerikil kasar.

Tabel 1. Kandungan Logam pada Limbah Padat IPAL Industri tekstil

\begin{tabular}{|c|c|c|}
\hline No. & Paramater & $\begin{array}{ll}\text { Sample } & \text { Result } \\
(\%) & \end{array}$ \\
\hline 1 & $\mathrm{SiO}_{2}$ & 0,3 \\
\hline 2 & $\mathrm{Al}_{2} \mathrm{O}_{3}$ & 24,7 \\
\hline 3 & $\mathrm{Fe}_{2} \mathrm{O}_{3}$ & 19,9 \\
\hline 4 & $\mathrm{CaO}$ & 9,36 \\
\hline 5 & $\mathrm{MgO}$ & 2,74 \\
\hline 6 & $\mathrm{~K} 2 \mathrm{O}$ & 1,53 \\
\hline
\end{tabular}


Limbah merupakan hal yang tidak bisa dihindari dari suatu prosen produksi. Berikut merupakan tabel kandungan logam yang terdapat pada limbah padat IPAL industri tekstil dari salah satu pabrik di Kawasan Berikat Nusantara yang telah di Uji di Laboraturium Kimia Universitas Indonesia:

Dari hasil uji kadar logam diatas dapat diambil kesimpulan bahwa dalam limbah padat IPAL industri tekstil tersebut terdapat kandungan logam yang paling dominan yaitu $\mathrm{Al}_{2} \mathrm{O}_{3}$ dan $\mathrm{Fe}_{2} \mathrm{O}_{3}$. Kadar $\mathrm{Al}_{2} \mathrm{O}_{3}$ atau aluminium oksida menunjukan yang tertinggi mencapaai $24,7 \%$, menurut Septiawardani (2012) kandungan alumunium oksida yang cukup merupakan salah satu materi pembentuk beton. Dengan kadar tersebut maka diharapkan akan dihasilkan beton yang mempunyai berat lebih ringan dibandingkan beton pada umumnya sehingga dapat mengurangi beban mati pada bangunan.

Kandungan $\mathrm{Fe}_{2} \mathrm{O}_{3}$ atau besi III oksida dalam limbah padat IPAL industri tekstil menunjukan angka tertinggi kedua yakni 19,9\%, merupakan logam yang dapat berfungsi sebagai tulangan pada pembuatan beton ini. Menurut Septiawardani (2012) besi selain menahan beban tarik juga dapat menahan tekan meskipun tidak maksimal. Gabungan antara besi dan alumunium ini diharap dapat membantu menahan beban tekan beton.

\section{Kuat Tekan Beton}

Mulyono (2003) menyatakan, kekuatan tekan merupakan salah satu kinerja utama beton. Kekuatan tekan adalah kemampuan beton untuk menerima gaya tekan persatuan luas. Walaupun dalam beton terdapat tegangan tarik yang kecil, diasumsikan bahwa semua tegangan tekan didukung oleh beton tersebut.

Menurut SNI 1974:2011, untuk menghitung kuat tekan benda uji dengan membagi beban maksimum yang diterima oleh benda uji selama pengujian dengan luas penampang melintang rata yang ditentukan, yaitu :

$$
\text { Kuat tekan beton }=\frac{P}{A}
$$


Keterangan:

Kuat tekan beton dengan benda uji silinder ( $\mathrm{MPa}$ atau $\mathrm{N} / \mathrm{mm}^{2}$ )

$\mathrm{P}=$ gaya tekan aksial, dinyatakan dalam Newton $(\mathrm{N})$

$\mathrm{A}=$ luas penampang melintang benda uji, dinyatakan dalam $\mathrm{Mm}^{2}$

\section{Hasil Penelitian}

Nilai slump dikelompokkan menurut variasi jumlah agregat halus yang disubtitusi dengan limbah. Hasil pengujian slump yang disubtitusi dengan limbah sebagai pengganti sebagian agregat halus dapat dibuat dalam grafik berikut:

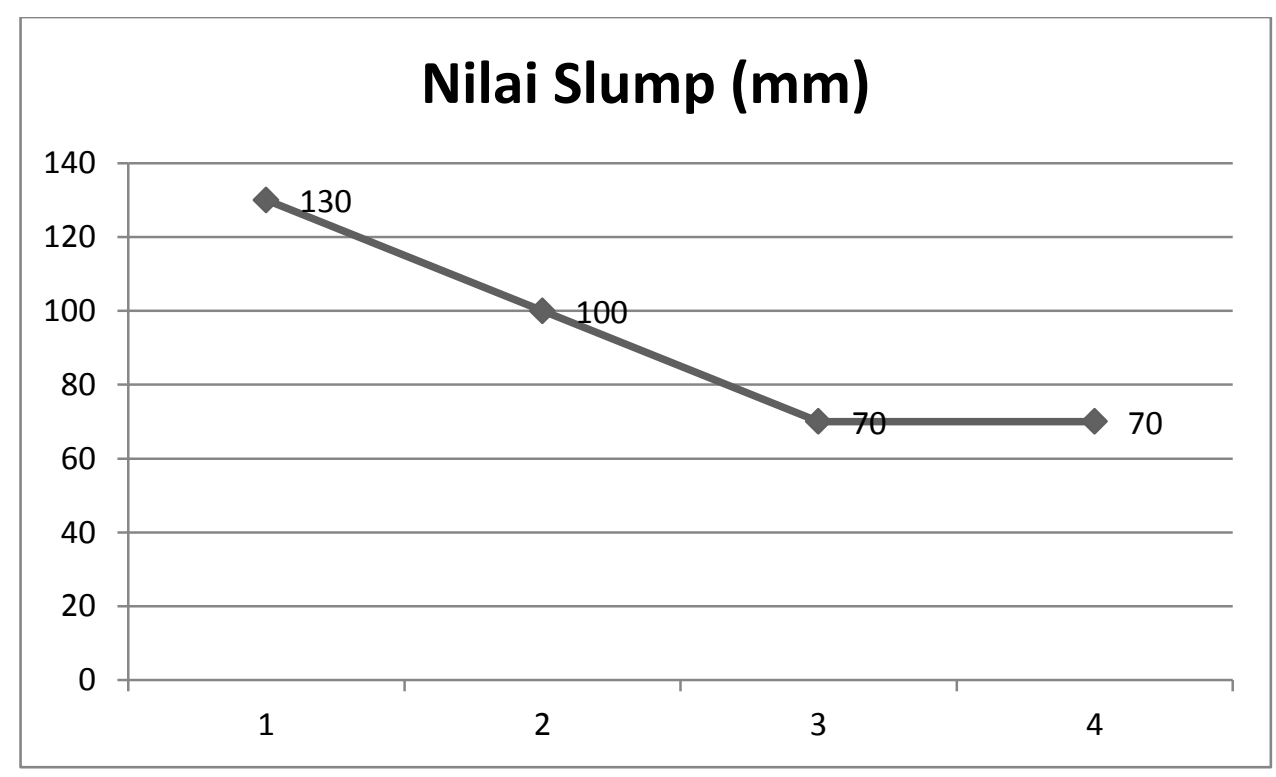

Gambar 1. Hasil Pengujian Slump

Berdasarkan gambar didapat nilai slump beton dengan subtitusi limbah yaitu 0\%, 20\%, 40\% dan $60 \%$ berturut-turut adalah $130 \mathrm{~mm} ; 100 \mathrm{~mm} ; 70 \mathrm{~mm}$; dan $70 \mathrm{~mm}$. Nilai slump beton normal dan beton dengan kandungan $20 \%$ limbah telah mencapai nilai yang telah direncanakan yaitu $120 \mathrm{~mm}+20 \mathrm{~mm}$, nilai slump ini merupakan nilai slump maksimum. Nilai slump minimum terdapat pada beton dengan kandungan limbah 40\% dan 60\% dari berat agregat halus dengan nilai $70 \mathrm{~mm}$. Dalam proses pembuatan benda uji dengan kandungan limbah 20\%, 40\% dan $60 \%$ pasta menempel pada dinding dinding molen yang mengakibatkan sulitnya proses pemadatan. Pada beton dengan limbah $40 \%$ dan $60 \%$ memiliki nilai slump yang sama hal ini dapat disebabkan karena cuaca hujan yang terjadi kerika pembuatan beton dengan kandungan 
$60 \%$ limbah yang mengakibatkan tingginya kandungan air pada bahan-bahan pembentuk benda uji tersebut.

Dapat disimpulkan bahwa dengan semakin bertambahnya kandungan limbah maka nilai slump yang dihasilkan semakin kecil. Hal ini dapat terjadi karena limbah banyak mengikat air yang mengakibatkan semakin banyak limbah yang digunakan semakin kecil pula nilai slump sesuai dengan hasil uji bahan yaitu limbah padat IPAL memiliki nilai penyerapan 13,2 kali lipat dibandingkan nilai kadar air dari pasir. Ditinjau dari kemudahan pengerjaannya semakin tinggi kandungan limbah yang digunakan maka semakin sulit pula proses pembuatan benda uji karena tingkat keplastisitasan yang semakin rendah menyebabkan sulitnya proses pemadatan.

Berat isi beton dikelompokkan menurut variasi jumlah agregat halus yang disubtitusi dengan limbah. Hasil penimbangan benda uji dapat dilihat dalam grafik berikut:

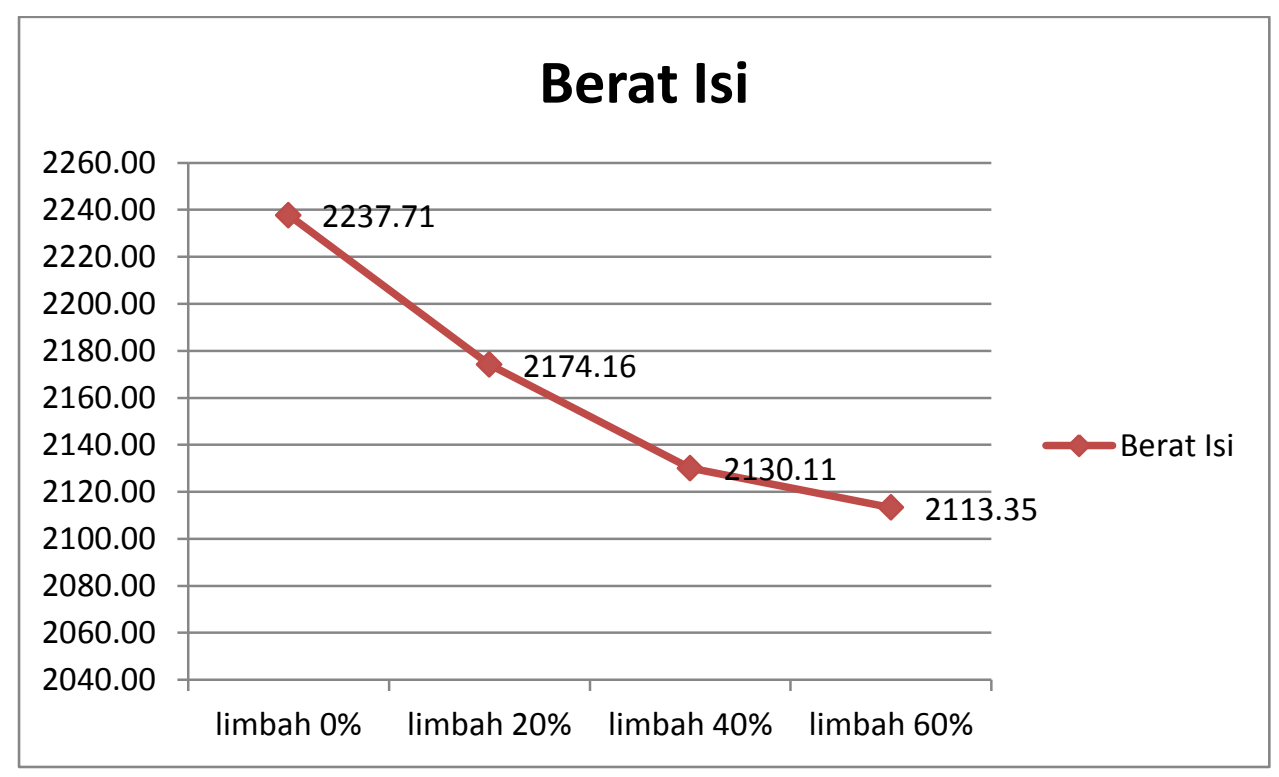

Gambar2. Grafik Berat Isi Benda Uji

Berdasarkan grafik dapat kita lihat bahwa penambahan limbah dapat mempengaruhi berat isi dari beton. Semakin menurunnya berat isi beton tersebut dapat disebabkan karena lebih rendahnya berat jenis SSD dari limbah padat IPAL industri tekstil tersebut. Berat jenis SSD limbah padat IPAL memiliki nilai lebih rendah 1,6 kali dibandingakan dengan berat jenis pasir yang digunakan. 
Kuat tekan beton dengan menggunakan limbah sebagai pengganti sebagian agregat halus dengan presentase $0 \%, 20 \%, 40 \%$, dan $60 \%$ dari berat agregat halus dilakukan di laboraturium uji bahan Universitas Negeri Jakarta. Kuat tekan dilakukan pada umur 7 dan 28 hari, adapun hasil dari uji kuat tekan dapat dilihat dalam diagram berikut:

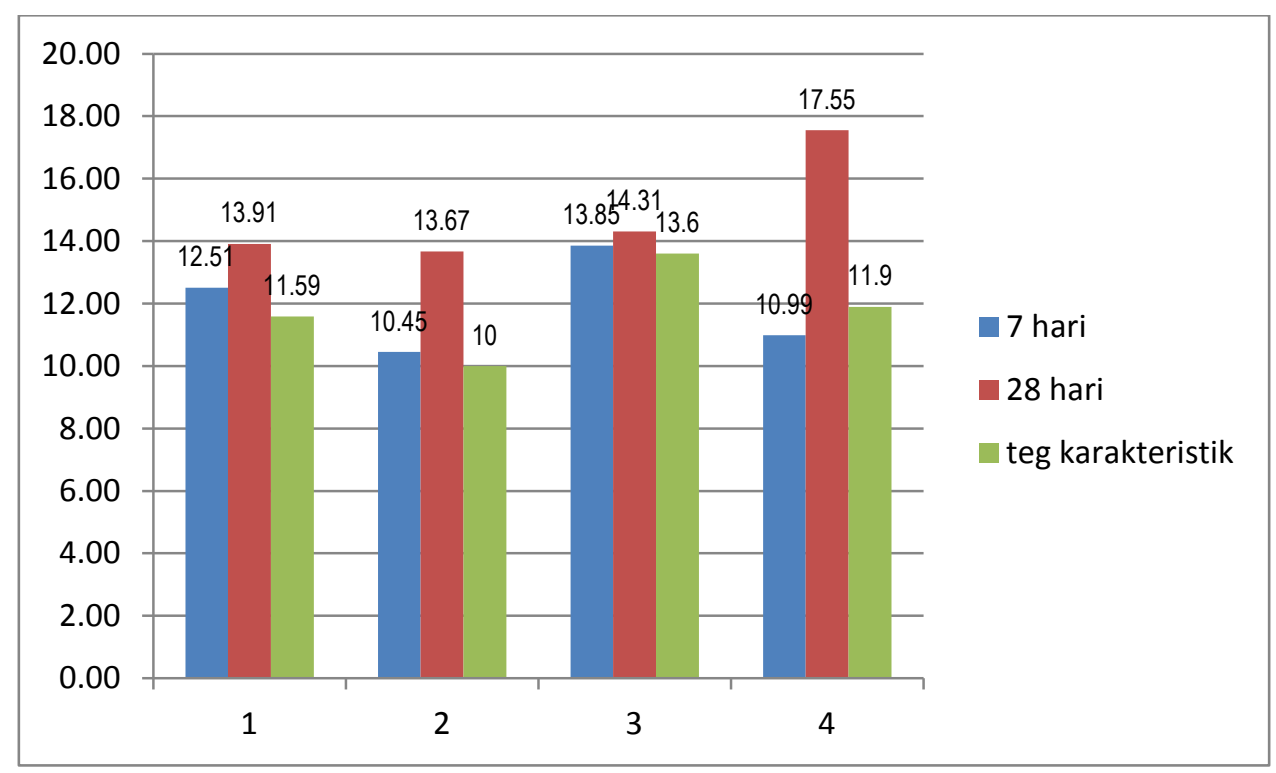

Gambar 3. Hasil Uji Kuat Tekan

Secara keseluruhan, perubahan kuat tekan dari berbagai variasi jumlah penggunaan limbah mempunyai perbedaan. Hasil pengujian seluruh variasi dapat dilihat pada grafik berikut:

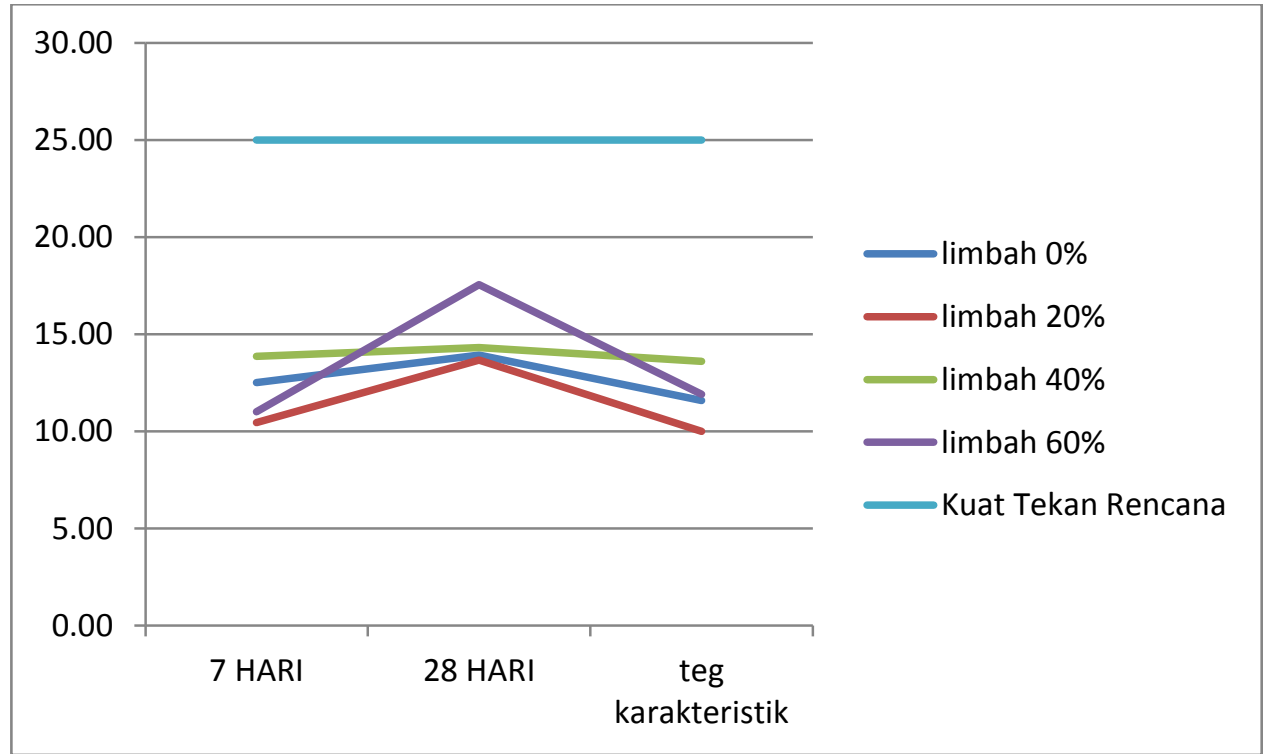

Gambar 4. Hasil Pengujian seluruh Variasi 
Berdasarkan grafik, kita dapat melihat bahwa kuat tekan beton maksimal terdapat pada kandungan limbah 60\% yang kuat tekannya dapat melebihi kuat tekan beton normal yaitu 18,8 Mpa. Nilai tersebut merupakan nilai yang cukup tinggi $21,25 \%$. Sehingga dapat ditarik kesimpulan bahwa penggunaan $60 \%$ limbah dapat meningkatkan kuat tekan sebesar $21,25 \%$.

Pada beton dengan kandungan limbah $60 \%$ pada usia 7 hari memiliki nilai kuat tekan yang lebih kecil jika dibandingkan dengan beton usia 28 hari. Hal ini dapat disebabkan karena pada beton usia 7 hari terjadi kebanjiran pada laboraturium dan beton usia 7 hari tersebut ikut terendam dan terkena lumpur dari banjir tersebut. Bercampurnya benda uji dengan lumpur banjir tersebut ternyata sangat mempengaruhi kuat tekan dari beton.

Perubahan nilai kuat tekan antara penggunaan limbah 40\% dan 60\% dapat disebabkan karena sulitnya proses pemadatan ketika $60 \%$. Seperti yang telah penulis jelaskan pada analisa penggunaan limbah $60 \%$ bahwa proses pengerjaan beton dengan kandungan limbah $60 \%$ sangat sulit meskipun dihasilkan nilai slump yang sama dengan beton yang mempunyai kandungan limbah 60\% namun beton dengan limbah 60\% memiliki tingkat kesukaran pengerjaan yang sangat karena pasta beton yang dihasilkan sangatlah lengket.

\section{KESIMPULAN}

Dari hasil penelitian dan pmbahasan maka, dapat disimpulkan bahwa:

1. Limbah padat IPAL industri tekstil dapat digunakan sebagai pengganti agregat halus karena mempunyai butir maksimum sebesar $4,75 \mathrm{~mm}$.

2. Proses pembuatan beton dengan menggunakan limbah padat IPAL industri tekstil memenuhi nilai slump rencana yaitu $120 \pm 20 \mathrm{~mm}$ pada proporsi $20 \%$ kandungan limbah padat IPAL industri tekstil sebagai pengganti sebagian agregat halus.

3. Penggunaan limbah padat IPAL industri tekstil sebagai pengganti sebagian agregat halus dapat meningkatkan kuat tekan beton pada proporsi $40 \%-60 \%$ dengan peningkatan kuat tekan sebesar $17,34 \%$ dan 2,6 dari beton normal

4. Proporsi maksimum pada beton yang menggunakan limbah padat IPAL industri tekstil sebagai pengganti sebagian agregat halus dengan rancangan campuran f'c $25 \mathrm{Mpa}$ dengan slump rencana $120 \pm 20 \mathrm{~mm}$ adalah dengan kandungan $40 \%$ limbah padat IPAL. Rata-rata

Pemanfaatan Limbah Padat IPAL Industri Tekstil sebagai Pengganti Ssebagian Agregat Halus 
kuat tekan tertinggi terdapat pada beton dengan kandungan limbah padat IPAL 40\% yaitu $13,6 \mathrm{Mpa}$

\section{DAFTAR PUSTAKA}

Amri, Sjafei. 2005. Teknologi Beton A-Z. Jakarta: Universitas Indonesia (UI-Press).

Badan Standar Nasional. 1990. SNI 03-1750-1990, Agregat Beton, Mutu dan Cara Uji. Jakarta: Departemen Pekerjaan Umum.

Badan Standar Nasional. 1990. SNI 03-1755-1990, Agregat Halus Aduk Beton, Cara Penentuan Kadar Zat Organik. Jakarta: Departemen Pekerjaan Umum.

Badan Standar Nasional. 1990. SNI 03-1968-1990, Agregat Halus dan Kasar, Metode Pengujian Analisis Saringan. Jakarta: Departemen Pekerjaan Umum.

Badan Standar Nasional. 1990. SNI 03-1974-1990. Metode Pengujian Kuat Tekan Beton. Jakarta: Departemen Pekerjaan Umum

Badan Standar Nasional. 1995. SNI 03-3976-1995, Tata Cara Pengadukan Pengecoran Beton. Jakarta: Departemen Pekerjaan Umum.

Badan Standar Nasional. 2000. SNI 03-2384-2000,Tata Cara Pembuatan Rencana Campuran Beton. Jakarta: Departemen Pekerjaan Umum.

Badan Standar Nasional. 2008. SNI 1970 : 2008, Cara Uji Berat Jenis dan Penyerapan Agregat Halus. Jakarta: Departemen Pekerjaan Umum.

Badan Standar Nasional. 2008. SNI 1969:2008, Cara Uji Berat Jenis dan Penyerapan Air Agregat Kasar. Jakarta: Departemen Pekerjaan Umum.

Badan Standar Nasional. 2008. SNI 1970:2008, Cara Uji Berat Jenis dan Penyerapan Air Agregat Halus. Jakarta: Departemen Pekerjaan Umum.

Badan Standar Nasional. 2008. SNI 2458 : 2008, Tata Cara Pengambilan Benda Uji Segar. Jakarta: Departemen Pekerjaan Umum.

Idaman, Nusa. 2005. Studi Kasus Pengolahan Air Limbah Pencucian Jeans. Jakarta: Badan Pusat Pengkajian dan Penerapan Teknologi

Junaidi. 2006. Analisis Teknologi Pengolahan Limbah Cair Pada Industri Tekstil. Badan Standar Nasional. 2004. SNI 15-2049-2004.Semen Portland. Jakarta: Departemen Pekerjaan Umum.

Mulyono, Tri. 2003. Teknologi Beton. Jakarta: ANDI Yogyakarta.

Septiandini, Erna. 2007. "Rencana Program Kegiatan Pembelajaran Semester (RPKPS) dan Bahan Ajar Mata Kuliah Praktek Uji Bahan, Prodi S1 Teknik Sipil, Fakultas Teknik, UNJ" Jakarta: Teknik Sipil Universitas Negeri Jakarta.

Tjokrodimulyo. 1996. Pengertian Beton. http://www.ilmusipil.com/pengertian-beton.html [22 Feb 2012]. 